\title{
Phytochemicals and antioxidant activities of twelve edible wild plants from Eastern Anatolia, Turkey
}

\author{
Kevser ALACA ${ }^{1}$, Emine OKUMUȘ ${ }^{1}$, Emre BAKKALBAȘI ${ }^{1 *}$ (D), Issa JAVIDIPOUR ${ }^{1}$
}

\begin{abstract}
Wild edible plants are important nutrient contributors in the diet of populations both in rural and urban areas. Eastern Anatolia has high plant diversity, and many plants are widely used as traditional food and medicine. In this study, approximate compositions, bioactive compounds and antioxidant capacities of twelve edible wild plants in Eastern Anatolia were investigated. L-ascorbic acid, total chlorophyll, total carotenoid and total phenolic contents of analyzed edible wild plants ranged from 1.03 to $10589.71 \mathrm{mg} / \mathrm{kg} \mathrm{dw}, 88.70$ to $1740.02 \mathrm{mg} / \mathrm{kg} \mathrm{dw}, 25.00$ to $700.20 \mathrm{mg} \beta$-car. eq. $/ \mathrm{kg} \mathrm{dw}$, and 444.14 to $2071.96 \mathrm{mg} \mathrm{GA} \mathrm{eq./} / \mathrm{kg} \mathrm{dw}$, respectively. Chlorogenic and gallic acids were the most abundant phenolic acids in the plant samples. Rutin, quarcetin, kaempferol and luteolin were identified and quantified in the samples. Luteolin $(15.98-832.82 \mathrm{mg} / \mathrm{kg} \mathrm{dw})$ was identified in almost all tested plants (except Coriandrum sativum). The results showed that Arum conophalloides, Rumex tuberosus, Rheum ribes, Plantago lanceolata, Tragopogon longirostris, and Chenopodium album had high contents of different phytochemicals, and antioxidant activities. These plants are available for a short time of the year and in small quantities. Future studies should be focused on biological, functional and toxicological assays and finally for commercial production of these promising plants.
\end{abstract}

Keywords: antioxidant activity; L-ascorbic acid; phenolics; pigments; wild edible plant.

Practical Application: Arum conophalloides, Rumex tuberosus, Rheum ribes, Plantago lanceolata, Tragopogon longirostris, and Chenopodium album grown in Eastern Anatolia are rich sources of phytochemicals.

\section{Introduction}

Plants have played an important role throughout the human history in all geographical regions of the World. They have been used for different purposes such as ingredients in different foods, ornamental materials, dye, traditional herbal medicine etc. For thousands of years, wild plants have been used in many cultures for vital nutrients and primary health care (Kaliora \& Dedoussis, 2007). World Health Organization (2013) advises and promotes the use of wild plants due to their local availability, cheapness and effectiveness. Nowadays, people are increasingly leaning towards the utilization of wild plants for their superior nutritional composition and therapeutic activity. Therefore, several researchers have studied the properties of traditional and wild edible plants (Sommano et al., 2013; Tunçtürk \& Özgökçe, 2015; Alam et al., 2020). Most of these studies have shown an important positive relationship between usage of these plants in diet, and health. This relationship is based on the fact that plants are the main sources of antioxidant phytochemicals such as carotenoids, tocopherols, phenolics, ascorbic acid etc (Sommano et al., 2013; Alam et al., 2020). Antioxidants are the most important parts of human nutrition due to the correlation of their intake with the lower incidence for chronic diseases associated with various inflammations and oxidative stresses such as cardiovascular diseases, cancer, diabetes and age-related degenerative processes (Kaliora \& Dedoussis, 2007; Alam et al., 2020).
The Eastern Anatolia is known for its high plant diversity and widespread traditional use of wild plants. Wild edible plants are an important part of diet of the urban and rural populations in the region. In urban areas, most of the wild edible plants are usually marketed through informal routes such as open markets and street vending. They are used as ingredients in preparation of different foods (cooked or stir-fried), production of dairy products (herby cheeses), brewed hot soft drinks and also directly used as fresh vegetables (Tunçtürk \& Özgökçe, 2015; Ocak et al., 2015).

Nowadays, with increasing the conscious regarding healthy foods in urban populations, the sales of wild edible plants have increased. Therefore, more work on bioactive compounds including antioxidant level is required to promote the native food, supplement, and pharmaceutical industry on nutritional benefits of native plants. This study was conducted to evaluate approximate composition, bioactive compounds and antioxidant capacity of the most widely used wild edible plants grown in Eastern Anatolia.

\section{Materials and methods}

\subsection{Plant materials}

Fresh plants of Arum conophalloides Kotschy ex Schott var. conophalloides (Khari), Gundelia tournefortii L. var. Tournefortii (Kenger), Eremurus spectabilis Bieb. (Çiriş), Tragopogon 
longirostris Bisch. Ex Schultz Bip. (Yemlik), Falcaria vulgaris Bernh. (Kaz ayağı), Rumex tuberosus L. subsp. horizontalis (Koch.) Rech. (Evelik), Rheum ribes L. (Uşgun), Chaeropbyllum macropodum Boiss. (Mendi), Cichorium intybus L. (Çatlanguş), Chenopodium album L. (Pazı), Coriandrum sativum L. (Kişniş) and Plantago lanceolata L. (Yllan Dili) were collected (500 g for each) from 4 different fields in rural area near the Van and Hakkari Cities (Eastern Anatolia, Turkey) during April and May 2017. The botanical identifications of the plants were done according to Flora of Turkey (Davis, 1985) with voucher specimens stored in the university herbarium by Prof. Dr. Murat Unal at Department of Biology Education in Van Yüzüncü Yıl University. The plant samples were immediately transported to the laboratory after collecting. Foreign materials were removed and then plants were washed and dried with paper towel. Fresh shoot of $G$. Tournefortii, stem and leaves of C. Macropodum, branch and leaves of C. Sativum and F. Vulgaris, stem of R. Ribes, and leaves of other plants were used for analyses. Finely freeze-dried samples were ground and kept in amber bottles under nitrogen gas at $-26^{\circ} \mathrm{C}$ for further analysis.

\subsection{Determination of dry matter, ${ }^{\circ} \mathrm{Brix}, \mathrm{pH}$, titratable acidity, ash and protein content}

Dry matter, ${ }^{\circ} \mathrm{Brix}, \mathrm{pH}$, titratable acidity, ash and protein contents were determined according to the methods given by AOAC (Association of Official Analytical Chemists, 2003).

\subsection{Total chlorophylls and carotenoids}

Total chlorophyll contents of samples were determined according to the method of Arnon (1949). Results were calculated using this formula: total chlorophylls $=(20.2 \times$ Abs645 $)+(8.02 \times$ Abs663 $)$. Total carotenoids content was determined using a spectrophotometric method described by Chan \& Cavaletto (1982). Results were calculated using this equation: total carotenoids $=$ (Abs444 $\mathrm{x}$ dilution coeff. $/$ extinction coeff. for $\beta$-carotenoid) x 10,000. They were expressed as milligrams of $\beta$-carotenoid equivalent per kilogram of sample on dry weight basis ( $\mathrm{mg} \beta$-car. eq. $/ \mathrm{kg} \mathrm{dw}$ ).

\subsection{L-Ascorbic acid}

Freeze-dried plant sample $(0.1 \mathrm{~g})$ was homogenized (30000 rpm, $30 \mathrm{~s}$ ) in ice bath with $2 \mathrm{~mL}$ of $4 \%$ metaphosphoric acid by a tissue homogenizer (Isolab, light duty model, China). Homogenate was centrifuged for $4 \mathrm{~min}$ at $10000 \times g$ and $4{ }^{\circ} \mathrm{C}$. Supernatant was filtered using a $0.45 \mu \mathrm{m}$ poly (vinylidene fluoride) syringe filter, and then immediately injected into a Shimadzu LC-20 AD HPLC system (Shimadzu, Kyoto, Japan). Atlantis dC18 $(250 \times 4.6 \mathrm{~mm}$ id, $5 \mu \mathrm{m}$ particle size $)$ was utilized with a mobile phase (water: $\mathrm{H}_{2} \mathrm{SO}_{4}, \mathrm{pH} 2.54$ ) at a flow rate of $0.7 \mathrm{~mL} / \mathrm{min}$. Detection was made at $244 \mathrm{~nm}$ and $25^{\circ} \mathrm{C}$. The $\mathrm{L}$-ascorbic acid appearing in chromatograms were identified on retention times and spectral data by comparison with standard (Lee \& Coates, 1999).

\subsection{Determination of flavonols}

Hydrolysis of flavonol glycosides was carried out with the method described by Park et al. (2014). Separation of flavonols in hydrolyzed sample was carried out by HPLC system (Shimadzu,
Kyoto, Japan $)$ equipped with a Symmetry C18 $(250 \times 4.6 \mathrm{~mm}$ id, $5 \mu \mathrm{m}$ particle size) column (Waters, USA) at $25^{\circ} \mathrm{C}$. A binary mobile phase consisting of $2 \%$ acetic acid in water $(\mathrm{A})$ and $0.5 \%$ acetic acid in water:acetonitrile $(1: 1, \mathrm{v} / \mathrm{v})(\mathrm{B})$ was used. Gradient program was as follow: $0 . \min 50 \% \mathrm{~A} ; 20$. min $10 \% \mathrm{~A} ; 28$. min $0 \%$ A. Detection was made at $360 \mathrm{~nm}$. The components appearing in the chromatogram were determined based on their retention times and spectral data by comparison with standards.

\subsection{Preparation of methanolic extract}

Freeze-dried plant sample $(0.5 \mathrm{~g})$ was put into a centrifuge tube and extracted by shaking with $9.75 \mathrm{ml}$ of methanol for $2 \mathrm{~h}$ at $175 \mathrm{rpm}$ in dark at room temperature. After shaking, mixture was centrifuged at $8000 \times g$ for $5 \mathrm{~min}$ at $4^{\circ} \mathrm{C}$ and then supernatant was transferred into an amber bottle. The above procedure was repeated twice using the residue. Supernatants were combined, and then final volume was adjusted to $10 \mathrm{ml}$ by rotary vacuum evaporator (IKA, RV 10 model, Germany). Methanolic extracts were stored in amber bottles under nitrogen atmosphere at $-26^{\circ} \mathrm{C}$, and used for determination of total phenolic content, phenolic profile and antioxidant activity.

\subsection{Total phenolic content}

Total phenolic content was determined by the Folin-Ciocalteau method (Singleton \& Rossi, 1965). Results were expressed as gallic acid equivalent (mg GA eq./kg dw).

\subsection{Phenolic profiles}

The phenolic profiles of plant samples were determined using the HPLC system (Shimadzu, Kyoto, Japan). Separation of phenolic compounds was carried out using a Symmetry C18 $(250 \times 4.6 \mathrm{~mm}$ id, particle size $5 \mu \mathrm{m})$ column (Waters, USA) at $25^{\circ} \mathrm{C}$. The method utilizes a binary mobile phase consisting of $2 \%$ acetic acid in water (A) and $0.5 \%$ acetic acid in water:acetonitrile $(1: 1, \mathrm{v} / \mathrm{v} ; \mathrm{B})$. Gradient program was as follows: 0 min $90 \% \mathrm{~A} ; 30 \mathrm{~min} 80 \% \mathrm{~A} ; 60 \min 65 \% \mathrm{~A}$. The flow rate was $1.0 \mathrm{~mL} / \mathrm{min}$. Detection was made at $280 \mathrm{~nm}$ for hydroxybenzoic acids and catechin, and at $320 \mathrm{~nm}$ for hydroxycinnamic acids. The compounds appearing in chromatograms were identified based on their retention times and spectral data by comparison with standards. The quantities of phenolic components were determined by proportioning the peak areas of the sample and standard (Colaric et al., 2005).

\subsection{DPPH and ABTS assays}

DPPH assay in methanolic extracts was performed using a spectrophotometric method described by Pyo et al. (2004). The ABTS assay was carry out according to the method described by Re et al. (1999). The results of both DPPH and ABTS assays were expressed as Trolox equivalent antioxidant capacity (mmol Tr. eq./g dw).

\subsection{Statistical analysis}

The study was carried out with 5 replications. Values are given as mean \pm standard deviation. The obtained data were analyzed using the SPSS package program version 22 for one-way 
analysis of variance (ANOVA). Duncan's multiple range test procedure was used to identify significant differences $(p<0.05)$. Correlation and Principal Component Analysis were performed with JMP 13 package program.

\section{Results and discussion}

\subsection{Chemical composition}

Some compositional properties of wild edible plants used in this study are given in Table 1 . Dry matter, ${ }^{\circ} \mathrm{Brix}$, ash, protein, $\mathrm{pH}$ and titratable acidity values of edible plants were $5.36-17.52 \%$, 4.37-10.20, 0.58-2.45\%, 1.35- 3.95\%, 4.03-7.34 and 0.17-1.04\%, respectively. While $P$. lanceolata showed the highest ${ }^{\circ}$ Brix value, $F$. vulgaris had the highest dry matter, protein and $\mathrm{pH}$ values. $R$. ribes showed the lowest ash, protein, $\mathrm{pH}$ and the highest titratable acidity values. Chenopodium album had the lowest dry matter, ${ }^{\circ}$ Brix and titratable acidity value. Very significant differences $(\mathrm{p}<0.05)$ were found among dry matters, ${ }^{\circ}$ Brix, ash, protein, $\mathrm{pH}$ and titratable acidity values of wild edible plants. The dry matter (5.28\%), ash (0.63\%) and protein (1.29\%) values reported by Andiç et al. (2009) for R. ribes were similar with our findings. While the protein (1.20\%) and $\mathrm{pH}$ (4.99) values noted by Tosun et al. (2012) for E. spectabilis were in good agreement with our results, dry matter (10.87\%), ash (0.87\%) and titratable acidity $(0.57 \%)$ values were higher than our results. However, Yildırım et al. (2001) reported higher dry matter (11.89\%) and protein $(3.69 \%)$ content and lower $\mathrm{pH}$ (6.32) value than ours for C. album.

\subsection{Chlorophyll and carotenoid contents of plants}

Chlorophylls find together with wide range of carotenoids in green plants. They are known to be the major pigments of green plants which carry out essential functions in the life cycle of green plants. Total chlorophyll contents of samples varied from 88.70 to $1740.02 \mathrm{mg} / \mathrm{kg} \mathrm{dw}$ (Table 2). While $G$. tournefortii and $R$. ribes had low total chlorophyll contents, C. sativum, R. tuberosus, A. conophalloides, T. longirostris and C. album showed higher values. Total chlorophyll contents of P. lanceolata samples varied between 2350 and $2390 \mathrm{mg} / \mathrm{kg} \mathrm{dw}$ (Tosserams et al., 2001). Ghasemi et al. (2018) noted that total chlorophyll contents of sixteen $R$. ribes samples ranged from 26 to $200 \mathrm{mg} / \mathrm{kg} \mathrm{dw}$. While our result for $R$. ribes was in the range of findings of Ghasemi et al. (2018), for P. lanceolata was lower than those reported by Tosserams et al. (2001).

Table 1. Some compositional properties of edible wild plants.

\begin{tabular}{|c|c|c|c|c|c|c|}
\hline Sample & Dry matter (\%) & Brix (\%) & Protein $(\%)$ & Ash (\%) & $\mathrm{pH}$ & Acidity (g/100g) \\
\hline C. macropodum & $9.54 \pm 0.75^{c}$ & $6.22 \pm 0.35^{\mathrm{b}}$ & $3.42 \pm 3.52^{\text {cde }}$ & $1.93 \pm 0.16^{\text {cde }}$ & $6.12 \pm 0.1^{b c}$ & $0.38 \pm 0.11^{\mathrm{ab}}$ \\
\hline E. spectabilis & $7.68 \pm 0.10^{\mathrm{bc}}$ & $5.55 \pm 0.57^{\mathrm{ab}}$ & $1.56 \pm 0.65^{\mathrm{ab}}$ & $0.60 \pm 0.10^{\mathrm{a}}$ & $5.15 \pm 0.41^{\mathrm{b}}$ & $0.39 \pm 0.02^{\mathrm{ab}}$ \\
\hline G. tournefortii & $7.61 \pm 0.15^{b c}$ & $6.23 \pm 1.37^{\mathrm{b}}$ & $2.53 \pm 0.81^{b c}$ & $1.13 \pm 0.15^{\mathrm{ab}}$ & $6.19 \pm 0.17^{b c}$ & $0.31 \pm 0.03^{\mathrm{ab}}$ \\
\hline C. intybus & $12.14 \pm 0.33^{\mathrm{d}}$ & $6.70 \pm 0.95^{b}$ & $3.62 \pm 0.25^{\text {cde }}$ & $1.83 \pm 0.34^{\mathrm{c}}$ & $6.11 \pm 0.24^{\mathrm{bc}}$ & $0.22 \pm 0.06^{\mathrm{ab}}$ \\
\hline C. album & $5.36 \pm 0.37^{\mathrm{a}}$ & $4.37 \pm 0.11^{\mathrm{a}}$ & $1.56 \pm 0.44^{\mathrm{ab}}$ & $1.20 \pm 0.12^{\mathrm{b}}$ & $6.73 \pm 0.09^{\mathrm{cd}}$ & $0.17 \pm 0.02^{\mathrm{a}}$ \\
\hline C. sativum & $9.30 \pm 0.60^{c}$ & $5.32 \pm 0.31^{\mathrm{ab}}$ & $3.76 \pm 0.05^{\mathrm{de}}$ & $1.40 \pm 0.06^{\mathrm{bc}}$ & $6.16 \pm 0.15^{b c}$ & $0.24 \pm 0.11^{\mathrm{ab}}$ \\
\hline T. longirostis & $16.88 \pm 0.55^{\mathrm{ef}}$ & $8.70 \pm 0.56^{c}$ & $3.32 \pm 0.02^{\text {cde }}$ & $2.45 \pm 0.56^{\mathrm{ef}}$ & $6.09 \pm 0.007^{b c}$ & $0.38 \pm 0.03^{\mathrm{ab}}$ \\
\hline F. vulgaris & $17.52 \pm 1.81^{\mathrm{f}}$ & $9.45 \pm 0.07^{\mathrm{cd}}$ & $3.95 \pm 0.79^{\mathrm{e}}$ & $2.13 \pm 0.38^{\mathrm{de}}$ & $7.34 \pm 2.26^{\mathrm{d}}$ & $0.34 \pm 0.02^{\mathrm{ab}}$ \\
\hline R. tuberosus & $12.06 \pm 0.89^{d}$ & $6.35 \pm 1.01^{\mathrm{b}}$ & $1.59 \pm 0.98^{\mathrm{ab}}$ & $1.78 \pm 0.89^{\mathrm{cd}}$ & $6.18 \pm 0.11^{b c}$ & $0.25 \pm 0.35^{\mathrm{ab}}$ \\
\hline R. ribes & $6.77 \pm 0.6^{\mathrm{ab}}$ & $5.68 \pm 0.18^{\mathrm{b}}$ & $1.35 \pm 0.65^{\mathrm{a}}$ & $0.58 \pm 0.16^{\mathrm{a}}$ & $4.03 \pm 0.04^{\mathrm{a}}$ & $1.04 \pm 0.26^{c}$ \\
\hline P. lanceolata & $16.31 \pm 1.61^{\mathrm{ef}}$ & $10.20 \pm 0.00^{\mathrm{d}}$ & $2.63 \pm 0.22^{\mathrm{bcd}}$ & $2.11 \pm 0.09^{\mathrm{de}}$ & $5.87 \pm 0.29^{b c}$ & $0.24 \pm 0.08^{\mathrm{ab}}$ \\
\hline A.Conophalloides & $9.01 \pm 0.64^{c}$ & $8.30 \pm 0.00^{c}$ & $3.66 \pm 0.09^{\text {cde }}$ & $0.79 \pm 0.01^{\mathrm{a}}$ & $6.08 \pm 0.02^{b c}$ & $0.25 \pm 0.00^{\mathrm{ab}}$ \\
\hline
\end{tabular}

Data are expressed as mean \pm standard deviation. Different superscript lowercase letters show differences among the plants $(\mathrm{p}<0.05)$.

Table 2. Total chlorophyll, total carotenoid, total phenolic content and antioxidant activity of edible wild plants

\begin{tabular}{|c|c|c|c|c|c|}
\hline \multirow{2}{*}{ Sample } & Tot Chlorophyll & Tot Carotenoid & TPC & \multirow{2}{*}{$\mathrm{DPPH}^{*}$} & \multirow{2}{*}{ ABTS $^{*}$} \\
\hline & $\mathrm{mg} / \mathrm{kg}$ DW & $\mathrm{mg} \beta$-car.eq./kg dw & mg GA eq./kg dw & & \\
\hline C. macropodum & $938.00 \pm 184.36^{\text {cd }}$ & $438.80 \pm 20.12^{c}$ & $444.14 \pm 287.92^{\mathrm{a}}$ & $6.23 \pm 1.64^{\mathrm{a}}$ & $22.13 \pm 8.03^{\mathrm{ab}}$ \\
\hline E. spectabilis & $644.97 \pm 90.99^{b}$ & $275.91 \pm 56.94^{\mathrm{b}}$ & $1224.39 \pm 192.28^{\mathrm{b}}$ & $17.24 \pm 5.67^{\mathrm{b}}$ & $27.68 \pm 1.71^{\mathrm{abc}}$ \\
\hline G. tournefortii & $88.70 \pm 15.35^{\mathrm{a}}$ & $25.00 \pm 1.77^{\mathrm{a}}$ & $851.01 \pm 131.85^{\mathrm{ab}}$ & $9.39 \pm 3.41^{\mathrm{a}}$ & $18.13 \pm 3.41^{\mathrm{a}}$ \\
\hline C. intybus & $1114.67 \pm 100.28^{\mathrm{d}}$ & $360.80 \pm 86.30^{b c}$ & $597.55 \pm 184.28^{\mathrm{ab}}$ & $5.18 \pm 1.15^{\mathrm{a}}$ & $27.80 \pm 1.27^{\mathrm{ab}}$ \\
\hline C. album & $1341.21 \pm 25.34^{\mathrm{e}}$ & $366.02 \pm 23.99^{b c}$ & $1232.73 \pm 102.66^{\mathrm{bc}}$ & $5.40 \pm 0.87^{\mathrm{a}}$ & $29.14 \pm 3.54^{\mathrm{bc}}$ \\
\hline C. sativum & $1740.02 \pm 3.82^{\mathrm{g}}$ & $700.20 \pm 48.24^{\mathrm{d}}$ & $498.25 \pm 255.98^{\mathrm{a}}$ & $8.46 \pm 3.16^{\mathrm{a}}$ & $26.09 \pm 2.81^{\mathrm{ab}}$ \\
\hline T. longirostis & $1401.36 \pm 92.29^{\mathrm{ef}}$ & $438.42 \pm 54.06^{\mathrm{c}}$ & $1245.92 \pm 117.17^{\mathrm{bc}}$ & $18.38 \pm 4.77^{\mathrm{bc}}$ & $36.95 \pm 4.77^{c}$ \\
\hline F. vulgaris & $895.12 \pm 88.92^{c}$ & $449.09 \pm 62.46^{c}$ & $599.99 \pm 181.20^{\mathrm{ab}}$ & $5.77 \pm 2.05^{\mathrm{a}}$ & $36.29 \pm 7.86^{c}$ \\
\hline R. tuberosus & $1544.29 \pm 169.39^{f}$ & $409.21 \pm 27.83^{b c}$ & $1727.64 \pm 496.05^{c}$ & $29.50 \pm 5.52^{\mathrm{d}}$ & $37.07 \pm 4.24^{\mathrm{c}}$ \\
\hline R. ribes & $155.77 \pm 25.95^{\mathrm{a}}$ & $34.63 \pm 0.54^{\mathrm{a}}$ & $1570.99 \pm 359.05^{c}$ & $27.70 \pm 4.84^{\mathrm{d}}$ & $25.81 \pm 8.91^{\mathrm{ab}}$ \\
\hline P. lanceolata & $854.23 \pm 9.79^{c}$ & $226.09 \pm 16.30^{\mathrm{b}}$ & $1319.89 \pm 197.31^{\mathrm{bc}}$ & $25.17 \pm 8.66^{\mathrm{cd}}$ & $24.94 \pm 6.39^{\mathrm{ab}}$ \\
\hline A. Conophalloides & $1435.16 \pm 56.98^{\mathrm{ef}}$ & $572.83 \pm 1.79^{\mathrm{cd}}$ & $2071.96 \pm 241.81^{\mathrm{c}}$ & $29.89 \pm 0.22^{\mathrm{d}}$ & $27.10 \pm 7.49^{\mathrm{ab}}$ \\
\hline
\end{tabular}

Data are expressed as mean \pm standard deviation. TPC: total phenolic content; ${ }^{\star}$ mmol Tr. eq./g dw. Different superscript lowercase letters show differences among the plants ( $\left.<<0.05\right)$. 
Carotenoids are accessory pigments in the light-harvesting steps of photosynthesis. They play an important role in human diet by virtue of their metabolism to vitamin A. In addition, high antioxidant properties of carotenoids have also been implicated in the protection against heart disease and cancer (Humphery \& Beale, 2006). The total carotenoid contents of selected edible plants were lower than their total chlorophyll contents. G. tournefortii ( $25 \mathrm{mg} \beta$-car. eq. $/ \mathrm{kg} \mathrm{dw}$ ) and $R$. ribes (34.63 $\mathrm{mg} \beta$-car. eq. $/ \mathrm{kg} \mathrm{dw}$ ) had low total carotenoid contents as well as their total chlorophyll contents (Table 2). C. sativum (700.20 mg $\beta$-car. eq. $/ \mathrm{kg} \mathrm{dw}$ ), A. conophalloides ( $572.83 \mathrm{mg}$ $\beta$-car. eq. $/ \mathrm{kg} \mathrm{dw}$ ), F. vulgaris (449.09 $\mathrm{mg} \beta$-car. eq. $/ \mathrm{kg} \mathrm{dw}$ ), C. macropodum (438.80 $\mathrm{mg} \beta$-car. eq. $/ \mathrm{kg} \mathrm{dw})$, T. longirostris (438.42 $\mathrm{mg} \beta$-car. eq. $/ \mathrm{kg} \mathrm{dw}$ ) and $R$. tuberosus (409.21 mg $\beta$-car. eq./kg dw) had high total carotenoids contents. Plant samples with high total carotenoid contents showed high total chlorophyll contents. However, C. macropodum and F. vulgaris with high total carotenoid contents had moderate total chlorophyll contents. Significant differences were observed among total chlorophyll and total carotenoids of all edible plants $(\mathrm{p}<0.05)$. Total chlorophyll and carotenoid contents of C. sativum were found as 1500 and $420 \mathrm{mg} / \mathrm{kg} \mathrm{dw}$, respectively (Idrees et al. 2010). Gupta \& Sinha (2007) reported that the total chlorophyll and carotenoid contents of C. album L. were around 1250 and $300 \mathrm{mg} / \mathrm{kg} \mathrm{dw}$, respectively. Both chlorophyll and carotenoid results of fresh samples reported in other studies were lower than our results.

\subsection{L-ascorbic acid contents of plants}

Ascorbic acid is commonly recognized as a major nutrient and antioxidant in food plants for human nutrition. Many health benefits have been attributed to ascorbic acid such as antioxidant, anti-atherogenic, anti-carcinogenic, antiinflammatory activities, immunomodulator and prevents cold, etc. Most plants and animals synthesize ascorbic acid for their own requirement. However, apes and humans cannot synthesize ascorbic acid due to the lack of gulonolactone oxidase. Hence, ascorbic acid has to be supplemented mainly through plants foods and tablets (Naidu, 2003). L-ascorbic acid contents were changed from 1.03 to $72.54 \mathrm{mg} / \mathrm{kg} \mathrm{dw}$ in most of the analyzed samples (Table 3). L-ascorbic acid contents of $R$. ribes
(1286.92 mg/kg dw) and A. conophalloides ( $10589.71 \mathrm{mg} / \mathrm{kg} \mathrm{dw})$ were significantly higher than those of the other tested plants $(\mathrm{p}<0.05)$. Our results for ascorbic acid were higher than the finding of Andiç et al. (2009) for R. ribes $(52.1 \mathrm{mg} / \mathrm{kg}$ ) and lower than that of Yildırım et al. (2001) for C. album $(423.8 \mathrm{mg} / \mathrm{kg}$ ). Variations may be due to differences in maturity levels, varieties, harvesting time, geographic locations, climate conditions and analysis methods. Especially A. conophalloides has very high L-ascorbic acid content. All parts of all species in the Arum genus are toxic (Nelson et al., 2007). However, the boiled or dried leaves are used as food and traditional herbal medicine for inflammatory diseases in Van province. Anti-inflamatory effect of $A$. conophalloides may be due to its very high $\mathrm{L}$ - ascorbic acid content. To our best knowledge, there is no report related to the L-ascorbic acid content of Arum species.

\subsection{Phenolic content and antioxidant activity}

Phenolic compounds are the most important bioactive compounds in plants, and have been extensively studied due to their diverse health benefits. In addition, they are the main contributors to the bitter and astringent taste of several edible plants. Total phenolic contents and antioxidant activities of samples were presented in Table 2. A. conophalloides had the highest (2071.96 mg GA eq./kg dw), and C. macropodum showed the lowest (444.14 mg GA eq./kg dw) total phenolic contents. Total phenolic contents of tested samples decreased in the following order: A. conophalloides $>$ R. tuberosus $>R$. ribes $>$ P. lanceolata $>$ T. longirostris $\geq$ C. album $\geq$ E. spectabilis $>$ G. tournefortii $>$ F. vulgaris $\geq$ C. intybus $>C$. sativum $>C$. macropodum. Significant differences were observed in total phenolic contents of samples $(\mathrm{p}<0.05)$. Samancioğlu et al. (2016) noted that the total phenolic contents of E. spectabilis, Rumex scatatus, $R$. ribes, T. longirostris and C. album were 323.4, 454.0, 233.2, 486.8 and $1030.0 \mathrm{mg} \mathrm{GA}$ eq./kg dw, respectively, which were higher than our findings. Total phenolic content of C. macropodum was found as $101.50 \mathrm{mg} \mathrm{GA}$ eq. $/ \mathrm{kg} \mathrm{dw}$ by Köse \& Ocak (2018), which was lower than our finding. Muñiz-Márquez et al. (2014) reported that total phenolic content of dried C. sativum was $1380 \mathrm{mg}$ GA eq. $/ \mathrm{kg}$.

Table 3. L-ascorbic acid and phenolic acid contents of edible wild plants ( $\mathrm{mg} / \mathrm{kg} \mathrm{dw}$ ).

\begin{tabular}{|c|c|c|c|c|c|c|c|}
\hline & \multirow{2}{*}{$\begin{array}{c}\text { L-ascorbic acid } \\
(\mathrm{mg} / \mathrm{kg} \mathrm{dw})\end{array}$} & \multicolumn{5}{|c|}{ Phenolic Acids (mg/kg dw) } & \multirow{2}{*}{ Catechin } \\
\hline & & Gallic & Chlorogenic & Ferulic & p-Qumaric & Syringic & \\
\hline C. macropodum & $2.56 \pm 0.20^{\mathrm{a}}$ & n.d. & $18.01 \pm 2.38^{\mathrm{a}}$ & $12.68 \pm 0.05^{\mathrm{a}}$ & n.d & n.d & $3.95 \pm 0.12^{\mathrm{a}}$ \\
\hline E. spectabilis & $24.85 \pm 2.12^{\mathrm{a}}$ & $35.77 \pm 14.06^{\mathrm{a}}$ & n.d. & n.d. & n.d. & n.d. & n.d \\
\hline G. tournefortii & $40.86 \pm 6.64^{\mathrm{a}}$ & n.d. & $388.30 \pm 23.13^{\mathrm{b}}$ & n.d. & $4.09 \pm 0.04^{\mathrm{a}}$ & n.d & n.d. \\
\hline C. intybus & $1.04 \pm 0.05^{\mathrm{a}}$ & n.d. & $122.82 \pm 78.42^{\mathrm{a}}$ & n.d. & n.d & n.d. & n.d \\
\hline C. album & $3.22 \pm 0.00^{\mathrm{a}}$ & $78.45 \pm 23.5^{\mathrm{ab}}$ & n.d. & n.d. & n.d. & n.d & n.d. \\
\hline C. sativum & $14.62 \pm 3.76^{\mathrm{a}}$ & $17.99 \pm 0.21^{\mathrm{a}}$ & $22.40 \pm 5.57^{\mathrm{a}}$ & n.d. & n.d & $6.93 \pm 0.04$ & $29.35 \pm 3.60^{\mathrm{b}}$ \\
\hline T. longirostis & $8.23 \pm 0.48^{\mathrm{a}}$ & $18.08 \pm 1.52^{\mathrm{a}}$ & $1058.81 \pm 12.3^{c}$ & n.d. & n.d. & n.d & n.d \\
\hline F. vulgaris & $72.54 \pm 28.81^{\mathrm{a}}$ & n.d. & $388.20 \pm 188.93^{\mathrm{b}}$ & n.d. & $4.06 \pm 0.10^{\mathrm{a}}$ & n.d. & n.d. \\
\hline R. tuberosus & $31.45 \pm 3.15^{\mathrm{a}}$ & $27.44 \pm 1.75^{\mathrm{a}}$ & $20.80 \pm 2.99^{\mathrm{a}}$ & $12.59 \pm 0.09^{\mathrm{a}}$ & n.d & n.d & n.d \\
\hline R. ribes & $1286.92 \pm 342.4^{\mathrm{b}}$ & $132.06 \pm 53.66^{\mathrm{b}}$ & n.d. & n.d. & n.d. & n.d. & $55.37 \pm 18.89^{c}$ \\
\hline P. lanceolata & $1.03 \pm 0.03^{\mathrm{a}}$ & n.d. & n.d. & n.d. & n.d & n.d. & $23.55 \pm 7.04^{\mathrm{ab}}$ \\
\hline A. Conophalloides & $10589.7 \pm 850.2^{c}$ & n.d. & $485.34 \pm 22.56^{\mathrm{a}}$ & n.d. & n.d. & n.d. & n.d. \\
\hline
\end{tabular}

Data are expressed as mean \pm standard deviation. n.d.: Not determined. Different superscript lowercase letters show differences among the plants (p $<0.05$ ). 
DPPH values of the tested plants varied from 5.18 to $29.89 \mathrm{mmol}$ Tr. eq./g dw (Tables 2). A. conophalloides showed the highest antioxidant activity against DPPH radical. $R$. tuberosus, $R$. ribes, $P$. lanceolate, T. longirostris and E. spectabilis also showed high DPPH radical scavenging capacity. Plants with high total phenolic contents showed higher antioxidant activities (except C. album). Interestingly, although C. album had high total phenolic content, it showed low DPPH radical scavenging activity. DPPH free radical scavenging activity values of tested plants showed very significant differences $(\mathrm{p}<0.05)$. Samancioğlu et al. (2016) noted that $\mathrm{IC}_{50}$ values of DPPH radical scavenging activities of E. spectabilis, $R$. scatatus, $R$. ribes, T. longirostris and C. album were 30.86, 26.66, 32.66, 71.00 and $18.66 \mathrm{mg}$ Tr. eq./g, respectively.

According to the ABTS method, antioxidant activities of the plants varied from 18.13 to $37.07 \mathrm{mmol} \mathrm{Tr}$. eq./g dw (Table 2). $R$. tuberosus, F. vulgaris and T. longirostris had the highest, and G. tournefortii showed the lowest ABTS values. Except R. tuberosus and T. longirostris, plants with more phenolic contents showed higher DPPH radical scavenging activities and moderate ABTS levels. Although, F. vulgaris had low phenolic content and DPPH value, it showed high ABTS value. This shows that DPPH analysis better reflects the contribution of phenolic content to antioxidant activity compared to ABTS analysis. The ABTS values of samples showed very significant differences $(\mathrm{p}<0.05)$. Köse \& Ocak (2018) noted that DPPH and ABTS values of $C$. macropodum were 114.60 and $642.4 \mathrm{mg}$ Tr. eq./ $\mathrm{kg} \mathrm{dw}$, respectively.

Major phenolic groups in plants are phenolic acids and flavonols (Pokorny et al., 2001). Phenolic acids of plant samples used in this study were given in Table 3. Chlorogenic acid was the major phenolic acid in most of the tested plant samples. Although chlorogenic acid was not detected in E. spectabilis, C. album, R. ribes and $P$. lanceolata, its levels in the other samples varied over a wide range (18.01-1058.81 mg/kg dw). The highest chlorogenic acid was found in T. longirostris samples. Gallic acid was the second most abundant phenolic acid ( 17.99 to $132.06 \mathrm{mg} / \mathrm{kg} \mathrm{dw}$ ). While $R$. ribes had the highest gallic acid content, it was not detected in A. conophalloides, C. macropodum, G. tournefortii, C. intybus, F. vulgaris, $P$. lanceolata. Ferulic acid levels in C. macropodum and $R$. tuberosus, p- qumaric acid in G. tournefortii and F. vulgaris and Syringic acid in C. sativum were found at low concentrations. In addition, catechin concentrations were found to be $3.95,29.35,55.37$ and $23.55 \mathrm{mg} / \mathrm{kg}$ dw in C. macropodum, $C$. sativum, $R$. ribes and $P$. lanceolata, respectively. The phenolic acid and catechin contents of samples showed very significant differences ( $\mathrm{p}<0.05)$. Dalar et al. (2016) noted that the total amounts of chlorogenic acid and its derivatives in P. lanceolata and C. intybus were trace amount and $17.0 \mathrm{mg}$ chlorogenic acid eq./g dw, respectively. Gallic acid content of sun-dried $R$. ribes sample reported by Meral (2017) was $345 \mathrm{mg} / \mathrm{kg}$. Our results regarding to gallic and chlorogenic acids were lower than those reported by Meral (2017) and Dalar et al. (2016), respectively.

Flavonols are very widespread compounds in the plant kingdom which are more abundant than phenolic acids in plants. They accumulated in roots and aerial parts (fruits, leaves, flowers, pollens, bark tissue and heartwood) of plants. Flavonols possess health-promoting effects, mainly because of their antioxidative properties (Andersen \& Markham, 2006). Four different flavonols (rutin, quarcetin, kaempferol and luteolin) were identified and quantified in plant samples (Table 4). Rutin was determined in C. macropodum, C. album, C. sativum, $R$. tuberosus and $R$. ribes. The rutin contents of tested plants varied from 17.70 to $1329.07 \mathrm{mg} / \mathrm{kg} \mathrm{dw}$. C. album had the highest rutin content. Quercetin was identified in G. tournefortii, C. intybus, C. sativum, R. tuberosus and R. ribes, ranged from 26.05 to $3347.71 \mathrm{mg} / \mathrm{kg} \mathrm{dw}$. $R$. tuberosus had the highest quercetin content. Kaempferol was detected in R. tuberosus and A. conophalloides, and its concentration was quite high in R. tuberosus $(2309.37 \mathrm{mg} / \mathrm{kg} \mathrm{dw})$. Luteolin was identified in almost all tested samples. Luteolin contents of samples ranged from 15.98 to $832.82 \mathrm{mg} / \mathrm{kg} \mathrm{dw}$. Luteolin was not detected in C. sativum. T. longirostris $(832.82 \mathrm{mg} / \mathrm{kg} \mathrm{dw}$ ) and P. lanceolata $(807.21 \mathrm{mg} / \mathrm{kg} \mathrm{dw})$ had highest luteolin contents. The flavonols contents of wild edible plants showed very significant differences ( $\mathrm{p}<0.05)$. Dalar et al. (2016) noted that $P$. lanceolata and C. intybus contained 41.1 and $7.8 \mathrm{mg}$ chlorogenic acid eq./g dw luteolin hexoside, respectively, and trace amounts of quercetin glucoside and quercetin rutinoside.

\subsection{Principal component analysis}

Principal component analysis (PCA) is one of the most frequently used data decompositions techniques. Reduction of the number of variables and detection structure in the relationship

Table 4. Flavonols contents of edible wild plants (mg/kg dw).

\begin{tabular}{|c|c|c|c|c|}
\hline Sample & Rutin & Quercetin & Kaempferol & Luteolin \\
\hline C. macropodum & $17.70 \pm 2.81^{\mathrm{a}}$ & n.d. & n.d. & $344.57 \pm 104.20^{b}$ \\
\hline E. spectabilis & n.d. & n.d. & n.d. & $48.25 \pm 23.38^{\mathrm{a}}$ \\
\hline G. tournefortii & n.d. & $56.78 \pm 26.14^{\mathrm{a}}$ & n.d. & $21.03 \pm 4.54^{\mathrm{a}}$ \\
\hline C. intybus & n.d. & $434.91 \pm 109.43^{\mathrm{a}}$ & n.d. & $46.30 \pm 15.95^{\mathrm{a}}$ \\
\hline C. album & $1329.07 \pm 367.58^{c}$ & n.d. & n.d. & $66.50 \pm 21.05^{\mathrm{a}}$ \\
\hline C. sativum & $357.86 \pm 189.99^{\mathrm{ab}}$ & $221.16 \pm 13.31^{\mathrm{a}}$ & n.d. & n.d. \\
\hline T. longirostis & n.d. & n.d. & n.d. & $832.82 \pm 307.45^{c}$ \\
\hline F. vulgaris & n.d. & n.d. & n.d. & $25.01 \pm 12.22^{\mathrm{a}}$ \\
\hline R. tuberosus & $495.83 \pm 222.40^{\mathrm{b}}$ & $3347.71 \pm 374.24^{\mathrm{b}}$ & $2309.37 \pm 67.16^{\mathrm{b}}$ & $15.98 \pm 3.77^{\mathrm{a}}$ \\
\hline R. ribes & $137.06 \pm 85.33^{\mathrm{ab}}$ & $26.05 \pm 0.50^{\mathrm{a}}$ & n.d. & $82.95 \pm 45.91^{\mathrm{a}}$ \\
\hline P. lanceolata & n.d. & n.d. & n.d. & $807.21 \pm 269.55^{c}$ \\
\hline A. Conophalloides & n.d. & n.d. & $56.62 \pm 0.69^{a}$ & $52.77 \pm 1.57^{\mathrm{a}}$ \\
\hline
\end{tabular}

Data are expressed as mean \pm standard deviation. n.d.: Not determined. 
between variables are the main applications of PCA (Kirazc1 \& Javidipour, 2008). PCA was used in the classification of some properties of plant samples. Using PCA based on the correlation matrix, eigenvalues, percentages of variation, and load coefficients of the first four principal components were calculated for all studied properties. PCA results are presented in terms of biplots (Fig. 1). It was found that the first four principal components accounted for $31.72,19.92,18.51$ and $11.88 \%$ of the variations, respectively. The cumulative proportion of the variation approached $82.03 \%$ of the total variance. The traits contributing to this high variation in first PCA component (PC 1) were dry matter, ash, titratable acidity, $\mathrm{pH}$, gallic acid and total chlorophyll parameters. Traits contributing to second PCA component (PC 2) were ${ }^{\circ}$ Brix value, luteolin, rutin and chlorogenic acid. The effects of traits on variation were similar in PCA 1 and PCA 2. However, the effects of titratable acidity and gallic acid in PCA 1 and rutin in PCA 2 are negative. The third PCA component (PCA 3) was basically related to the quercetin, DPPH, ABTS and total phenolic content. The effect of total phenolic content was higher than other traits in PCA 3. Traits contributing to fourth PCA component (PC 4) were protein, L-ascorbic acid and total carotenoid. The effect of L-ascorbic acid (0.64) was higher than other traits in PCA 4. According to these results, $\mathrm{pH}$, dry matter, ${ }^{\circ} \mathrm{Brix}$ value, ash and protein were positively correlated with each other although only ash was negatively correlated with L-ascorbic acid and titratable acidity $(\mathrm{p}<0.01)$. Although titratable acidity was positively correlated with L-ascorbic acid, gallic acid and catechin, it was negatively correlated with $\mathrm{pH}$, total chlorophyll and total carotenoid contents. $\mathrm{pH}$ was significantly correlated

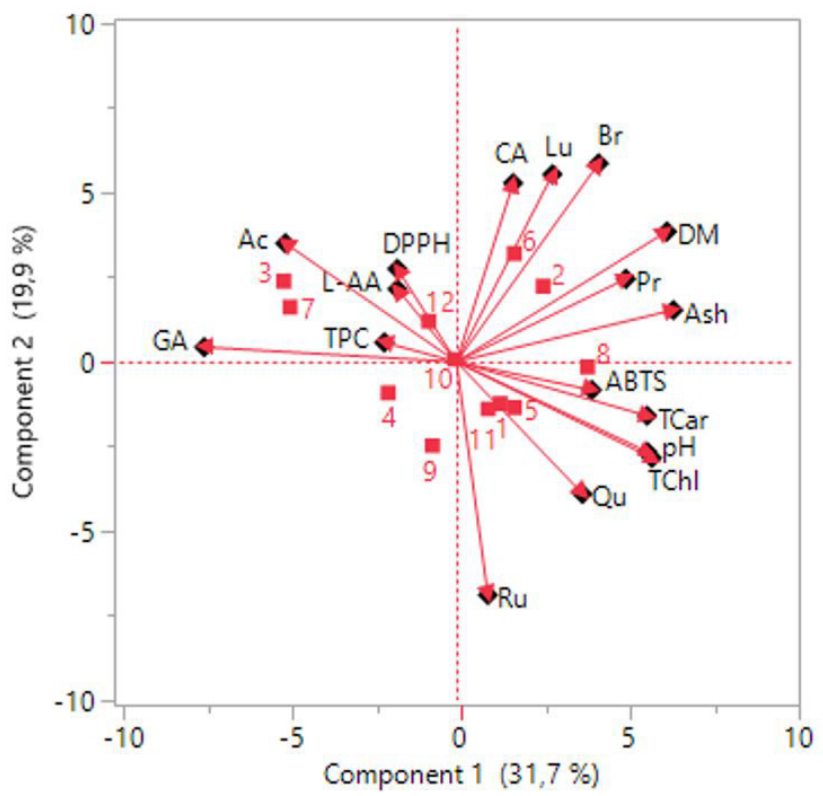

Figure 1. Biplot PCA results (1- $R$ tuberosus, 2- T longirostris, 3- G tournefortii, 4- E spectabilis, 5- C intybus, 6- Planceolata,7- Rheum ribes, 8- F vulgaris, 9- $C$ album, 10- $C$ macropodum, 11- $C$ sativum, 12- A. Conophalloides, ABTS- ABTS, Ac- titratable acidity, Ash-ash, Br- obrix, CA- chlorogenic acid, DM- dry matter, DPPH- DPPH, GA- gallic acid, L-AA- L-ascorbic acid, Lu- luteolin, $\mathrm{pH}$ - $\mathrm{pH}$, Pr- protein, Qu- quercetin, Ru- rutin, TCar- total carotenoid, TChl- total chlorophyll, TPC- total phenolic content). with most of the analyzed parameters including; rutin, gallic acid, catechin, dry matter, ash, protein, titratable acidity, DPPH, L-ascorbic acid, total chlorophyll and total carotenoid. Total phenolic content was positively correlated with $\mathrm{L}$-ascorbic acid, quercetin, catechin and DPPH. However, total phenolic content was not correlated with ABTS. While ABTS was correlated with quercetin, and total chlorophyll, DPPH was correlated with quercetin, catechin, protein, titratable acidity, total phenolic content and L-ascorbic acid. The results suggest that DPPH may be more useful for assaying the antioxidant activity in plants than ABTS, because DPPH shows good correlation with several antioxidant compounds.

\section{Conclusion}

Plants are good dietary sources of health-promoting phytochemicals, and consequently show high antioxidant activity. Results showed that the A. conophalloides, R. tuberosus, $R$. ribes, $P$. lanceolata, $T$. longirostris, and C. album had higher amounts of different phytochemicals (ascorbic acid, carotenoid, chlorophyll and phenolics) and higher antioxidant activities than the other tested plants. While C. album had high rutin and total phenolic contents, T. longirostris was a rich source of chlorophyll, chlorogenic acid and luteolin. $R$. ribes was a good source of L-ascorbic acid and gallic acid. A. conophalloides contained very high level of L-ascorbic acid and had the highest total phenolic content and DPPH radical scavenging activity. $R$. tuberosus showed the high levels of chlorophyll, quercetin, kaempferol, total phenolic content and antioxidant activity (both DPPH and ABTS assays). Further researches including biological, functional and toxicological assays should be done for national and international recognition in the marketing of these plants. Commercial production of these plants which are only available for a short time of the year will be provide a substantial boost to the economy of rural areas.

\section{Acknowledgements}

The authors would like to thanks Prof. Dr. Murat Ünal for the botanical identifications of the plants and Van Yüzüncü Yll University Research Fund for financial support (FYL-2018-7226).

\section{References}

Alam, M. K., Rana, Z. H., Islam, S. N., \& Akhtaruzzaman, M. (2020). Comparative assessment of nutritional composition, polyphenol profile, antidiabetic and antioxidative properties of selected edible wild plant species of Bangladesh. Food Chemistry, 320, 126646. http://dx.doi.org/10.1016/j.foodchem.2020.126646. PMid:32229398.

Andersen, Q. M., \& Markham, K. R. (2006). Flavonoids: chemistry, biochemistry and application. USA: CRC Press.

Andiç, S., Tunçtürk, Y., Ocak, E., \& Köse, S. (2009). Some chemical characteristics of edible wild rhubarb species (Rheum ribes L.). Research Journal of Agriculture and Biological Sciences, 5(6), 973-977.

Arnon, D. I. (1949). Copper enzymes in isolated chloroplasts. Polyphenoxidase in Beta vulgaris. Plant Physiology, 24(1), 1-15. http://dx.doi.org/10.1104/pp.24.1.1. PMid:16654194.

Association of Official Analytical Chemists - AOAC. (2003). Official methods of analysis of the Association of Official Analytical Chemists. Washington: AOAC. 
Chan, H. T., \& Cavaletto, C. G. (1982). Aseptically packaged papaya and guava puree: Changes in chemical and sensory quality during processing and storage. Journal of Food Science, 47(4), 1164-1169. http://dx.doi.org/10.1111/j.1365-2621.1982.tb07641.x.

Colaric, M., Veberic, R., Solar, A., Hudina, M., \& Stampar, F. (2005). Phenolic acids, syringaldehyde, and juglone in fruits of different cultivars of Juglans regia L. Journal of Agricultural and Food Chemistry, 53(16), 6390-6396. http://dx.doi.org/10.1021/jf050721n. PMid:16076123.

Dalar, A., Uzun, Y., Turker, M., Mukemre, M., \& Konczak, I. (2016). Health attributes of ethnic vegetables consumed in the Eastern Anatolia region of Turkey: antioxidant and enzyme-inhibitory properties. Journal of Ethnic Foods, 3(2), 142-149. http://dx.doi. org/10.1016/j.jef.2016.05.005.

Davis, P. H. (1985). Flora of Turkey and the East Aegean Islands. Edinburgh: Edinburgh University Press.

Ghasemi, G., Fattahi, M., \& Alirezalu, A. (2018). The study of phytochemical properties and antioxidant activity of different genotypes Rheum ribes $\mathrm{L}$. collected from different regions of Iran. Journal of Food Research Agricultural Science, 28(4), 73-88.

Gupta, A. K., \& Sinha, S. (2007). Phytoextraction capacity of the Chenopodium album $\mathrm{L}$. grown on soil amended with tannery sludge. Bioresource Technology, 98(2), 442-446. http://dx.doi.org/10.1016/j. biortech.2006.01.015. PMid:16540314.

Humphery, A. J., \& Beale, M. H. (2006). Terpens, In: A. Croizer, M. N. Clifford, H. Ashihara (Eds.), Plant secondary metabolites (pp. 47-101). Oxford: Blackwell Publishing Ltd. http://dx.doi. org/10.1002/9780470988558.ch3.

Idrees, M., Khan, M. M. A., Aftab, T., \& Naeem, M. (2010). Synergistic effects of gibberellic acid and triacontanol on growth, physiology, enzyme activities and essential oil content of Coriandrum sativum L. The Asian and Australasian Journal of Plant Science and Biotechnology, 4(1), 24-29.

Kaliora, A. C., \& Dedoussis, G. V. (2007). Natural antioxidant compounds in risk factors for CVD. Pharmacological Research, 56(2), 99-109. http://dx.doi.org/10.1016/j.phrs.2007.04.018. PMid:17572098.

Kirazc1, A., \& Javidipour, I. (2008). Some chemical and microbiological properties of ghee produced in Eastern Anatolia. International Journal of Dairy Technology, 61(3), 300-306. http://dx.doi.org/10.1111/j.14710307.2008.00402.x.

Köse, Ş., \& Ocak, E. (2018). Antimicrobial and antioxidant properties of sirmo (Allium vineale L.), mendi (Chaerophyllum macropodum Boiss.) and siyabo (Ferula rigidula DC.). Gida, 43, 294-302. http:// dx.doi.org/10.15237/gida.GD17099.

Lee, H. S., \& Coates, G. A. (1999). Vitamin C in frozen, fresh squeezed, unpasteurized, polyethylene-bottled orange juice: a storage study. Food Chemistry, 65(2), 165-168. http://dx.doi.org/10.1016/S03088146(98)00180-0.

Meral, R. (2017). The effect of different temperatures on antioxidant activity and phenolic profile of the Rheum ribes. Yuzuncu Yil University Journal Agricultural Sciences, 27(1), 88-94.

Muñiz-Márquez, D. B., Rodríguez, R., Balagurusamy, N., Carrillo, M. L., Belmares, R., Contreras, J. C., Nevárez, G. V., \& Aguilar, C. N. (2014). Phenolic content and antioxidant capacity of extracts of Laurus nobilis L., Coriandrum sativum L. and Amaranthus hybridus
L. CYTA: Journal of Food, 12(3), 271-276. http://dx.doi.org/10.108 0/19476337.2013.847500.

Naidu, K. A. (2003). Vitamin C in human health and disease is still a mystery? An overview. Nutrition Journal, 2(1), 7. http://dx.doi. org/10.1186/1475-2891-2-7. PMid:14498993.

Nelson, L. S., Shih, R. D., \& Balick, M. J. (2007). Handbook of poisonous and injurious plants (2nd ed.). New York: Springer Media and New York Botanical Garden.

Ocak, E., Javidipour, I., \& Tunçtürk, Y. (2015). Volatile compounds of Van herby cheeses produced with raw and pasteurized milks from different species. Journal of Food Science and Technology, 52(7), 43154323. http://dx.doi.org/10.1007/s13197-014-1458-8. PMid:26139896.

Park, S., Arasu, M. V., Jiang, N., Choi, S. H., Lim, Y. P., Park, J. T., Al Dhabi, N. F., \& Kim, S. J. (2014). Metabolite profiling of phenolics, anthocyanins and flavonols in cabbage (Brassica Oleracea Var. Capitata). Industrial Crops and Products, 60, 8-14. http://dx.doi. org/10.1016/j.indcrop.2014.05.037.

Pokorny, J., Yanishlieva, N., \& Gordon, M. (2001). Antioxidants in food: practical applications. Boca Raton: CRC Press Cambridge.

Pyo, Y. H., Lee, T. C., Logendra, L., \& Rosen, R. T. (2004). Antioxidant activity and phenolic compounds of swiss chard (Beta Vulgaris Subspecies Cycla) extracts. Food Chemistry, 85(1), 19-26. http:// dx.doi.org/10.1016/S0308-8146(03)00294-2.

Re, R., Pellegrini, N., Proteggente, A., Pannala, A., Yang, M., \& RiceEvans, C. (1999). Antioxidant activity applying an improved ABTS radical cation decolorization assay. Free Radical Biology \& Medicine, 26(9-10), 1231-1237. http://dx.doi.org/10.1016/S0891-5849(98)003153. PMid:10381194.

Samancıoğlu, A., Sat, I. G., Yıldırım, E., Ercișli, S., Jurikova, T., \& Mıcek, T. (2016). Total phenolic and vitamin $C$ content and antiradical activity evaluation of traditionaly consumed wild edible vegetables from Turkey. Indian Journal of Traditional Knowledge, 15(2), 208-213.

Singleton, V. L., \& Rossi, J. A. (1965). Colorimetry of total phenolic with phosphomolybdic -phosphotungstic acid reagents. American Journal of Enology and Viticulture, 16, 144-158.

Sommano, S., Caffin, N., \& Kerven, G. (2013). Screening for antioxidant activity, phenolic content, and flavonoids from Australian native food plants. International Journal of Food Properties, 16(6), 1394-1406. http://dx.doi.org/10.1080/10942912.2011.580485.

Tosserams, M., Smet, J., Magendans, E., \& Rozema, J. (2001). Nutrient availability influences UV-B sensitivity of Plantago lanceolata. Plant Ecology, 154(1/2), 157-168. http://dx.doi.org/10.1023/A:1012927706903.

Tosun, M., Ercisli, S., Ozer, H., Turan, M., Polat, T., Ozturk, E., Padem, H., \& Kilicgun, H. (2012). Chemical composition and antioxidant activity of foxtail lily (Eremurus spectabilis). Acta Scientiarum Polonorum. Hortorum Cultus, 11(3), 145-153.

Tunçtürk, M., \& Özgökçe, F. (2015). Chemical composition of some Apiaceae plants commonly used in herby cheese in Eastern Anatolia. Turkish Journal of Agriculture and Forestry, 39, 55-62. http://dx.doi. org/10.3906/tar-1406-153.

World Health Organization - WHO. (2013). WHO traditional medicine strategy 2014-2023. Switzerland: WHO Press.

Yıldırım, E., Dursun, A., \& Turan, M. (2001). Determination of the nutrition contents of the wild plants used as vegetables in upper Coruh valley. Turkish Journal of Botany, 25, 367-371. 